\section{En oplysende, men lettere uorganiseret religionshistorie}

Tim Jensen, Mikael Rothstein og Jorgen Podemann Sorensen (red.): Gyldendals Religionshistorie. Ritualer, Mytologi, Ikonografi (2. reviderede og udvidede udgave), Gyldendal, 2011, 763 sider med illustrationer, 549,95 kr.

Den nye og reviderede udgave af Gyldendals Religionshistorie kommer vidt omkring i religionernes verden, både historisk og geografisk. Her er megen værdifuld viden at hente for den almindelige læser, der er interesseret i religion, og for fagfolk, der har brug for et enkelt opslagsværk. Når det er sagt, rejser undertitlen 'Ritualer, Mytologi og Ikonografi' forventninger, der ikke fuldt ud indfries. Sagt i en sidebemærkning forekommer begrebssammenstillingen mig taxonomisk upræcis: Begrebet 'mytologi' betegner i fagsproget en sammenfatning af eller lære om forskellige fortælletraditioner, mens disse traditioner i sig selv kaldes 'myter'. Disse kan som sådan indgå i et tættere eller løsere forhold til riter, større rituelle sammenhænge (ceremonier eller kultfester af flere dages varighed) og ikonografiske fremstillinger af forskellig art. Men lad blot dette være en petitesse. Værre er det nok, at man skal kigge langt efter en systematisk præsentation af de forskellige religiøse traditioners rituelle, mytiske og ikonografiske udtryksformer, som stilles læseren i udsigt. Måske ville det slet ikke have været hensigtsmæssigt at presse de enkelte monografiske fremstillinger ned i samme skabelon, men når de enkelte kapitler fremstår så forskellige, som tilfældet er i denne bog, bærer det ikke desto mindre præg af et lidt for tilbagetrukket redaktionsarbejde.

Jørgen Podeman Sørensens indledning, der fænomenologisk redegør for forskellige og netop tværkulturelle aspekter af 'Ritualer, Mytologi og Ikongrafi' fungerer for så vidt fint i sig selv, men følges ikke op af de enkelte bidrags interne organisering. I den omtalte indledning angives den grundlæggende forskel og sammenhæng mellem rite og myte med filologisk præcision som det af Galen omtalte forhold mellem dromena (det, der gøres) og legomena (det, der siges), men det lades uomtalt, at der specifikt refereres til de eleusinske mysterier i oldtidens Grækenland, og det er derfor også et spørgsmål, hvor megen vægt, denne distinktion kan bære i komparativ henseende.

At en manglende ensartethed i 
opbygningen af de enkelte kapitler gør sig gældende vidner følgende underoverskrifter i nogle udvalgte kapitler med al tydelighed om: I det oplysende kapitel om Ægyptisk religion, som samme Podeman Sørensen er forfatter til, angiver afsnitsoverskrifterne en gennemgang af Mytologi og Kult og efter nogle udvalgte eksempler herpå en kort presentation af Hinsides billeder. I kapitlet om Mesopotamisk religion er afsnittene opdelt i Kilderne, Kosmologi, Guder og damoner, Den offentlige kult, Templer og endelig Etik. I modsætning til de forrige kapitler indledes kapitlet om Iransk religion ikke med en redegørelse for kildesituationen, men i stedet indføres der generelt til den historiske kontekst. Herefter følger afsnit om Teologi, Mytologi, Ritualer, ceremonier og fester (hvilket i øvrigt rejser et spørgsmål til, hvorfor vi ikke har fået præciseret en religionshistorisk brug af begrebet 'teologi'). Kapitlet om det Gamle Israels religion lægger ud med Nybrud i forskningen og indeholder ikke herudover afsnit, der kan sammenlignes med de foregående kapitler. Generelt gælder det, at mens nogle af kapitlerne gør grundigt rede for kildesituationen (som f.eks. Erik Reenberg Sands fremstilling af Vedisk religion og Jens Peter Schjødts fremstilling af Nordisk religion), udelades dette næsten helt $\mathrm{i}$ andre (som f.eks. Mikael Aktors fremstilling of Jainismen og Häkan Rydvings fremstilling af Det cirkumpolare område). Det er klart, at de forskellige kulturelle sammenhænge inviterer til forskellige forskningsmæssige indfaldsvinkler, men dette kunne i det mindste have været ekspliciteret. Det skal retfærdigvis siges, at vi finder masser af omtale af myter (og mytologi), ritualer og ikonografi i de forskellige monografiske fremstillinger, men den systematik, der kunne have hjulpet læseren til en mere komparativ forståelse, mangler. Endvidere kan det umiddelbart undre, at en religionshistorisk fremstilling, der ret konsekvent satser på monografiske fremstillinger af de forskellige religioner, indføjer et afsnit om Vestens esoteriske traditioner. Kapitlet, der er forfattet af Olav Hammer, indleder upræcist med en henvisning til, at:

den vesterlandske idehistorie bygger på en arv: den jodisk-kristne (som netop havder, at viden kommer via en tradition bygget på en hellig skerift), den rationalistiske (viden kommer ved, at man drager rationelle slutninger ud fra det, man kan erfare ved bjalp af sanserne) og den esoteriske (viden kommer til os via religiose eksperters gnosis) (s. 298)

Jeg har dels problemer med den udifferentierede brug af vidensbegrebet, dels med generaliseringen 
af den jødisk-kristne tradition, der bl.a. har muliggjort den vesterlandske sekularisering, og endelig er sammenblandingen af rationalisme og empirisme uheldig. Bortset herfra spænder kapitlet vidt (med mange interessante oplysninger) og udfoldes under en fænomenologisk præmis, der ikke genkendes fra de andre bidrag. At placere det sammen med de to kapitler, der tildeles Kristendommen inden for den hovedsektion, der bærer overskriften Kristendom og den vestlige verdens religionshistorie, er måske også noget af en tilsnigelse, dels fordi kristne og ikke-kristne traditionselementer blandes sammen (jf. det fænomenologiske undtagelseskriterium), dels fordi den vestlige verdens religionshistorie vel også må siges at indbefatte såvel græske som romerske, keltiske, semitiske og muslimske traditioner.

Særligt interessant $i$ et religionshistorisk oversigtsværk som det her foreliggende er det at finde en afsluttende sektion om 'Religiøs Innovation'. Ligesom sektionerne om Jødedom og Islam består den blot af et enkelt kapitel, forfattet af Olav Hammer og Mikael Rothstein, der kommer godt omkring forskellige kendte og mindre kendte 'nyreligiøse bevægelser', som de konsekvent sammenfatter under overskriften 'Nye religioner'. Det er næppe tilfældigt, at der tales om religioner og ikke blot om nyreligiose bevagelser, for det fremgår klart, at institutionaliserede fænomener som Scientology-kirken, Moonbevægelsen, TM og andre sekter betragtes som regulære religioner. Religionshistorien er således rig på eksempler med nydannelser, der låner fra ældre, eksisterende traditioner. Det er der ikke i sig selv noget nyt eller enestående i, og det siges derfor mellem linjerne, at der ikke gives noget fagligt argument for at betragte noget som mere religion end andet. De abrahamitiske traditioner er blot ældre end de moderne knopskydninger, men grundlæggende set ikke udtryk for fænomener, der metodisk eller begrebsligt bør betragtes forskelligt fra disse. Det nævnes ganske vist $i$ forbigående som en mulighed, at der siden 1800-tallet har været tale om nogle mere omfattende samfundsændringer, der kan have præget de "moderne religiøse bevægelser", men det affærdiges dog hurtigt som mindre vigtigt (s. 742). For mig at se afslører dette strukturelt orienterede og historisk udglattende syn på fænomenet religion imidlertid et idehistorisk deficit. Det er vel ikke den helt store kunst at påpege alle mulige strukturelle og morfologiske ligheder, men spørgsmålet er, hvor meget 
det siger i sig selv, for endnu mere afhænger af hvilke aspekter, man har i kikkerten. Hvad værre er: det skænker os ikke noget kriterium for at skelne imellem tradition og efterligning. Man kan selvfølgelig indvende, at behovet for et sådant kriterium netop afslører en fordom om, at der overhovedet behøver at være tale om en forskel mellem 'ægte' tradition og 'uxgte' efterligning. Hvorfor kan vi ikke med samme ret sige, at alt er tradition, eller at alt er efterligning? Det kan vi selvfølgelig også, men dermed svigter vi den kritiske forsknings opgave. Kritik betyder på græsk at kende forskel. Og det er vi mindst lige så forpligtet til at gøre som til at påpege ligheder. Ville man ikke forvente af et værk, der kalder sig Religionshistorie, at de kulturelle fænomener, som det siden oplysningstiden har været almindeligt at sammenfatte under betegnelsen religion, ses $i$ lyset af de historiske forandringsprocesser, der overhovedet tillod dem at komme til syne? Når vi i dag (og mere eller mindre siden Hume og Kant) bruger begrebet 'religion', taler vi grundlæggende om et fænomen, der kan klassificeres separat som netop religion, men sådan har det ikke altid været. Sådan var det ikke i Grækenland, da man talte om orgia, mysteria og om dromena og legomena, og sådan var det heller ikke i de 'abrahamitiske religioner' før reformationen, for der var ikke tale om noget, der var forskelligt fra samfundet $\mathrm{i}$ almindelighed. Ganske vist opstod der forskellige sekt-dannelser, der ligesom moderne New Age-fænomener tog, hvad de kunne bruge fra andre sammenhænge. Det er et sociologisk fænomen, vi har kendt til alle tider. Men er det ensbetydende med, at den grundlæggende orienteringsramme er den samme til alle tider? Vil en overfokusering på strukturelle ligheder ikke skygge for dybtgående mentalitetshistoriske og epistemiske forskelle, som en vederhæftig religionshistorie alt andet lige må tage højde for? Det er min klare opfattelse, at denne mere idehistoriske side af sagen, som redaktørerne nok burde have ført tilsyn med, halter noget bagefter den ellers fagkyndige buket af de mange enkeltkapitlers spændende og lærerige fremstillinger.

Lars Albinus 